\title{
Who can Really be Called a Lexicographer?
}

Rufus H. Gouws, Department of Afrikaans and Dutch, University of Stellenbosch, Stellenbosch, South Africa (rhg@sun.ac.za)

\begin{abstract}
Lexicographers define words but still lack a clear and unambiguous understanding of the word lexicographer. This paper gives a brief discussion of the problems experienced in trying to determine exactly what a lexicographer is. The distinction between theoretical and practical lexicographers is quite clear but within both these categories there are grey areas where it is not so clear whether a specific participant in lexicographic activities qualifies to be called a lexicographer. The lack of formal professional lexicographic qualifications impedes an unambiguous understanding of the word. The emergence of lexicography as an independent discipline compels lexicographers to take a closer look at criteria relevant to identifying someone as being a lexicographer.

Keywords: EMLEX, LEXICOGRAPHER, LEXICOGRAPHIC PRACTICE, LEXICOGRAPHIC PROCESS, LEXICOGRAPHIC RESEARCH, LEXICOGRAPHIC TRAINING, METALEXICOGRAPHER, PRACTICAL LEXICOGRAPHER, PRIMARY LEXICOGRAPHER, SECONDARY LEXICOGRAPHER, THEORETICAL LEXICOGRAPHER
\end{abstract}

Opsomming: Wie kan werklik 'n leksikograaf genoem word? Leksikograwe definieer woorde, maar dit ontbreek hulle steeds aan 'n ondubbelsinnige verstaan van die woord leksikograaf. Hierdie artikel bied 'n bondige bespreking van probleme wat ervaar word wanneer gepoog word om werklik te begryp wat 'n leksikograaf is. Die onderskeid tussen teoretiese en praktiese leksikograwe is redelik duidelik, maar binne albei hierdie kategorieë is daar grys gebiede waar dit nie sonder meer gesê kan word of 'n bepaalde deelnemer aan leksikografiese aktiwiteite wel daarvoor kwalifiseer om 'n leksikograaf genoem te word nie. Op internasionale vlak bemoeilik die gebrek aan formele professionele leksikografiese kwalifikasies 'n ondubbelsinnige begrip van die woord. Die ontluiking van leksikografie as 'n onafhanklike dissipline dwing leksikograwe om nouer ondersoek in te stel na daardie kriteria wat ter sake is om iemand as 'n leksikograaf te kan identifiseer.

Sleutelwoorde: EMLEX, LEKSIKOGRAAF, LEKSIKOGRAFIESE NAVORSING, LEKSIKOGRAFIESE OPLEIDING, LEKSIKOGRAFIESE PRAKTYK, LEKSIKOGRAFIESE PROSES, METALEKSIKOGRAAF, PRAKTIESE LEKSIKOGRAAF, PRIMÊRE LEKSIKOGRAAF, SEKONDÊRE LEKSIKOGRAAF, TEORETIESE LEKSIKOGRAAF

\section{Introduction}

"Who can really be called a lexicographer?" can be regarded as one of the most unlikely and even most inappropriate questions to be put to the readers of a 
journal focusing exclusively on lexicographic matters. However, although the range of answers to this question will have a lot in common there will also be some differences. These differences may lead to interesting discussions.

In dictionaries a variety of definition types are used. One of these definition types is the circular definition - a type that is not applauded elsewhere but utilised in dictionaries due to its space-saving value. A typical example of the use of a circular definition in a dictionary would be to define the word lexicographer as "someone working within the field of lexicography". Such a circular definition is only permissible if the word lexicography has been included as a lemma of which the article contains a clarifying definition. This paper will not attempt to answer the question "What is lexicography?" However, in working with the premise that a lexicographer is someone involved in the field of lexicography some aspects regarding lexicography and lexicographers will be discussed.

\section{The problem}

A question like "Who is an engineer?"or "Who is an architect?" can easily be answered by referring to the academic and professional qualifications needed for someone to be called an engineer or an architect. The answer to a question like "Who is a gardener?" is not to be answered that unambiguously. Is it someone exclusively working in gardens, someone doing it as a hobby, someone doing it under protest but because he/she has a garden that needs to be taken care of they have to do some gardening work? Fortunately or unfortunately there are no formal internationally recognised and accepted professional qualifications that can be used to uniquely identify someone as being a lexicographer. Fortunately there are people involved in lexicographic activities: either on a fulltime basis, or as a hobby or even under protest, e.g. when a publishing house needs to produce a dictionary and someone has to do the job. Peoples' involvement in lexicography covers a wide-ranging variety of lexicographic activities. Some talk about dictionaries without ever having compiled one. Some people are involved in lexicographic activities because they develop computer programmes for dictionaries, or they do the marketing of a dictionary, or they proofread a dictionary manuscript, or they design the lay-out of a dictionary or they review dictionaries for popular or academic publications. But does this involvement in lexicographic activities qualify all of them to be called lexicographers?

In recent decades it has been the case that many lexicographers have been people with a formal training in linguistics, cf. Atkins (2002: 25) saying:

The most significant difference, I believe, between the 1967 lexicography and that of today is that in the interval my approach to lexicography has benefited from the insights of linguistics. ... Linguistic theory, particularly recent work in lexical semantics, can light the way to better lexicography. 
But very seldom did this training in linguistics include any direct reference to lexicography or to dictionaries. Although training in linguistics can be a valuable aid when compiling certain types of dictionaries it is no prerequisite for being a lexicographer, and when planning and compiling e.g. a dictionary of medical and health terms very little linguistic training is put to use. It is only in the last ten to fifteen years that formal academic programmes like the MPhil/MA and DLitt/PhD in Lexicography have been offered, e.g. at the University of Stellenbosch, South Africa, and it is only since 2011 that the European Masters in Lexicography (EMLex) has been an option at a number of European universities. Students completing these courses have a formal academic qualification in lexicography - just as students completing a degree in e.g. engineering have a formal academic qualification in engineering. Do these students with an engineering qualification have to embark on a specific project to be called an engineer? Do students completing the academic programmes in lexicography have to work on a dictionary project to be called lexicographers?

A recent advertisement for the post of "Senior Editor, Dictionaries" at a South African publishing house states that the position includes "compiling, editing and proof checking dictionary products". These are lexicographic activities, albeit that the advertisement does not call this editor a lexicographer! When it comes to the requirements for the post the advertisement guides potential candidates by means of a hierarchical set of criteria, distinguishing in descending order between "requirements", "highly recommended" and "recommended". Requirements are e.g. indicated as "highly computer literate" and "a good understanding of editorial and production processes", Highly recommended is indicated as e.g. "professional experience developing or producing dictionaries" and "interest in how South Africans use dictionaries" whilst Recommended is indicated as e.g. "driver's licence and willingness to undertake occasional travel" and "linguistic or lexicographic training". For this position of lexicographer, lexicographic training is regarded on par with having a driver's licence and of an inferior value to being highly computer literate.

The implications of this advertisement should compel people involved in the field of lexicographic training to a process of self-reflection regarding the quality and contents of their training programmes and the needs and requirements of the market for their products, but it also gives us a good idea of what a publishing house regards as important criteria for their future lexicographers. Which combination and ordering of these criteria will be needed to ensure that the successful candidate can be called a lexicographer?

\section{The factual situation}

Lexicography has two major components, i.e. a theoretical component and a practical component. When being "involved in lexicographic activities" this involvement could refer to either or to both of these components. Gouws (2006) has identified four types of lexicographers: 
- those working in the lexicographic practice without any theoretical experience;

- those working in theoretical lexicography without any practical experience;

- those working primarily as practical lexicographers but with some theoretical experience;

- those working primarily as theoretical lexicographers but with some practical experience.

However, such a distinction does not go beyond the initial definition of "someone working within the field of lexicography". But how are lexicographers defined by their fellow lexicographers?

\section{Existing dictionary definitions}

Arguably the best known definition of a lexicographer is that by Samuel Johnson (1755):

A writer of dictionaries; a harmless drudge that busies himself in tracing the original, and detailing the signification of words.

Along with numerous other definitions the core of the definition given by Johnson lies in the fact that a lexicographer is primarily regarded as a writer of dictionaries. A much broader approach is found in the Wikipedia definition:

A person devoted to lexicography is called a lexicographer. (Wikipedia, the Free Encyclopedia)

This definition implies that the writing of dictionaries is not the only criterion to qualify someone for being a lexicographer. Bergenholtz and Gouws (2012) have argued that a lexicographer could be a person with a practical or a theoretical involvement in lexicography. The question to be asked in this regard goes to the nature and the extent of this involvement.

Looking at lexicographers and their practical work it is also important to distinguish between the different types of dictionaries compiled by these lexicographers. Different sets of opposites could be taken into account. One such distinction is that between linguistic and encyclopedic dictionaries and a second distinction is that between general language dictionaries and specialised dictionaries. In one of the early typological classifications of lexicographic works, Zgusta (1971) already made provision for encyclopedias as belonging to the family of dictionaries. The need to include this type of reference work within the lexicographic family was also emphasised by Ilson (1988) when stating his policy as first editor of the International Journal of Lexicography: 
Our primary concern is with reference works that give lexically relevant information about lexically relevant items. But we realise that the problems facing compilers and users of dictionaries and thesauruses are similar to those facing compilers and users of indexes, encyclopaedias, atlases, and other types of reference work, and our pages are open to the discussion of their problems, too.

This statement of Ilson does not imply that the compiler of an atlas is a lexicographer but it does broaden the domain of lexicographic work, i.e. the domain of labour of the lexicographer. The definition of a lexicographer could therefore even bear reference to someone involved in the compilation of other lexical reference works comparable to dictionaries. This issue will not be discussed here. However, it is relevant to note that suggestions have already been made that the application of lexicographic theory should be extended and applied to a broader category of reference works, cf. Gouws (2011).

The second distinction, i.e. between LGP and LSP dictionaries, is also important for the interpretation of the term lexicographer. If it is argued that a lexicographer is someone involved in the compilation of a dictionary the reference to "dictionary" does not imply only general language dictionaries. One of the results of acknowledging lexicography as an independent discipline is that dictionaries constitute the subject matter of lexicography. Whereas linguists would be interested in the linguistic contents of general language dictionaries they have little linguistic interest in e.g. the structure of dictionaries or the contents of dictionaries dealing with languages for special purposes like dictionaries of chemistry, gene technology, statistics or psychology. Albeit true that LSP dictionaries are lexicographic products, their compilers do not have to be linguists or people with any linguistic training. Not being a linguist does not influence the status of the compilers of these dictionaries as being lexicographers.

\section{Theoretical and practical lexicographers}

With lexicography consisting of two components and lexicographers defined as people involved in lexicographic activities it would be a logical conclusion to say that lexicographers also fall into two groups, i.e. theoretical and practical lexicographers.

\subsection{Theoretical lexicographers}

People working in the field of theoretical lexicography are also lexicographers, often called metalexicographers. They are those scholars dedicating time and research endeavours to the formulation of lexicographic models, discussions of dictionary structures, lexicographic functions, the contents of dictionaries, dictionary typology, dictionary use, dictionary criticism, etc. In this regard it is important to look at the different components of theoretical lexicography, e.g. as indicated by Wiegand (1984), and to refer to participants in these different 
components of theoretical lexicography as metalexicographers.

But how does the scope of the term lexicographer compare to that of theoretical lexicography? The theoretical component of the work of lexicographers can be divided into at least two major categories: doing research in and writing about lexicography and, secondly, devising course material for lexicographic programmes and teaching lexicography; in short the research and the training components of this endeavour.

There will be little doubt that people writing text books with lexicography as topic, writing papers on lexicographic topics for scientific journals, writing papers for lexicography conferences, doing research for advanced degrees in lexicography and people developing theoretical models for practical dictionary projects can be called lexicographers, more specifically metalexicographers. A question that comes to the fore is the degree and level of involvement here that is needed to qualify someone as being called a lexicographer. What kind of research outputs are required? When it comes to teaching and training, lexicography is taught as an academic subject in a number of university programmes. In the majority of cases it is done as part of a programme in language or linguistics; in only a few instances as part of a formal qualification in lexicography. In very few instances universities have a staff member appointed specifically to teach lexicography. Where this is the case and it is expected from such a staff member to teach lexicography and to supervise advanced postgraduate research but also to do research in lexicography and publish in scientific journals such a professor in lexicography will necessarily qualify to be called a metalexicographer. But when it comes to teaching there is a question as to what can be regarded as the minimum of teaching and the lowest level of teaching done to qualify the presenter as a metalexicographer? Does the teaching of a single undergraduate module dealing with a few aspects of lexicography qualify its presenter to be called a lexicographer? Is it sufficient if the teaching is restricted to dictionary using skills or should it be a more comprehensive treatment of the field of lexicography? Is teaching and training sufficient or should research and research outputs be prerequisites for someone to be called a lexicographer? These questions have not yet been answered sufficiently.

Metalexicographers can be seen as people devoting time and effort to research in the field of lexicography and also people applying this knowledge in teaching and training programmes in order to equip potential practical lexicographers with the necessary expertise to do their work. But in both the main components of research and training it is unclear what the minimum criteria are to qualify someone as a metalexicographer. For the further development of lexicography as a fully-fledged field it is necessary to formulate a clear set of criteria that can distinguish lexicographers from non-lexicographers.

\subsection{Practical lexicographers}

The biggest grey area when it comes to determining who a lexicographer is, lies in the domain of the lexicographic practice. Without any question someone 
writing a dictionary, no matter what type of dictionary, can be called a lexicographer. In this regard it is important to have a clear indication of what a dictionary is. This is especially relevant within the field of LSP lexicography. Terminological lists and glossaries are often called dictionaries. If the compilation of such a dictionary merely demands from someone to select the relevant items to be included as lemmata and to order them alphabetically, a real question can be put as to whether he/she can be called a lexicographer. Here it is important to realise that any lexicographic process consists of different phases, cf. Wiegand (1998), and people involved in these different phases are needed to ensure the eventual production and success of the envisaged dictionary. In many dictionary projects different members of the team participate in different phases of the process. One of these phases is the selection of items to be included as lemmata in a dictionary. This is an extremely important phase and the nature and extent of the treatment allocated to these items do not make the selection less vital as a phase in the lexicographic process. The person responsible for this selection surely has to be regarded as a lexicographer. So even if the eventual dictionary is only a word list, the person responsible for the selection of the items to be included as lemmata and who compiles that lexicographic product qualifies to be called a lexicographer, even if he/she merely executes a dictionary plan compiled by a theoretical lexicographer.

One of the implications of lexicography being regarded as an independent discipline and not a subdiscipline of linguistics is the fact that LSP dictionaries fall within the scope of lexicography, albeit that they do not fall within the scope of linguistics. In recent years LSP dictionaries have often been the result of a team effort in which one or more subject field experts combine with one or more established lexicographers, e.g. the recently published Woordeboek vir die Gesondheidswetenskappe/Dictionary for the Health Sciences (Lochner 2011). In these cases the established lexicographer will devise the plan for the dictionary. The subject field expert will supply the subject specific data to be included in the dictionary. Such a subject field expert primarily functions within his/her field and is not primarily a lexicographer. While working together with the established lexicographer to compile a dictionary he/she supplies the relevant subject matter for the specific dictionary and by doing so also becomes a lexicographer - but in a different way compared to the established lexicographer. As a lexicographer he/she contributes in terms of dictionary contents selected for a given target group but usually does not contribute to the working out of the plan of the dictionary or in presenting the data in order to satisfy the envisaged functions of the dictionary.

In some dictionary projects individual team members are only responsible for specific data types. One person would take the responsibility for data regarding pronunciation, another for etymological data, a third for morphological data, etc. Each member of the team contributes to the writing of the dictionary but can each one be called a lexicographer? Someone exclusively responsible for etymology gets the assignment on account of his/her expertise as an etymologist. He/she is not responsible for the lexicographic treatment of 
a given word but only to give its etymology - so that it can be presented as an item in a dictionary article. Is he/she an etymologist, a lexicographer, an etymological lexicographer or a lexicographical etymologist?

In this regard it seems as if a distinction can be made between primary and secondary lexicographers. This might imply that there is a hierarchy of some being "more" or "less" lexicographers than others.

The editorial team of many dictionaries also include members that are not directly involved in the process of writing the dictionary. One such member is the computer specialist who designs the programme for the dictionary. Such a programme is specifically designed for a given dictionary. It forms an integral part of the lexicographic process. This team member should also be regarded as lexicographer due to his/her involvement in the lexicographic process but he/she could be named more clearly as a computational lexicographer or even a lexicographical computer specialist.

Where dictionaries include pictorial illustrations in the articles artists are usually commissioned to make the drawings or to design the pictures. These artists do not need any lexicographic skills in order to do their duty. They are asked to make drawings of e.g. a tortoise, cell phone or space shuttle. Whether it is for a dictionary or a comic does not really matter to them. The lexicographer will give them directions regarding the focus, dimensions, etc. of the pictures to be drawn. Although it is important that the picture should satisfy the criteria set by the lexicographer in order to fulfil its function as a dictionary entry, the artist merely executes the orders without bringing lexicographic criteria into play. The artist plays a role in the preparation of the data to be included in the dictionary but does not qualify to be called a lexicographer because their work is not of a lexicographic nature although it is done for inclusion in a dictionary.

The proofreaders of a dictionary also play an important role in the success of the final outcome. They need to be familiar with the editorial system of the dictionary in order to execute their proofreading successfully. However, the work they do remains proofreading and not lexicographic work. Therefore the nature and extent of their role in the lexicographic process do not qualify them to be called lexicographers.

The grey area in the field of lexicographic practice is not as grey as it might seem. Those participants in the lexicographic process whose work demands a form of lexicographic training are lexicographers; those who perform work for the dictionary but not work that qualifies as a lexicographic endeavour should not be called lexicographers. However, lexicographers need to formulate criteria according to which one can unambiguously identify someone as being a lexicographer or not.

\section{In conclusion}

Those members of homo sapiens who carry the title "lexicographer" constitute 
a small and intriguing category. However, even for a lexicographer it is not always as easy to say where exactly the boundaries of this group of people are. There is a core of people involved in lexicographic activities that qualify in the minds of most people to be called lexicographers. This core, including metalexicographers and practical lexicographers (some primary and others secondary lexicographers) is surrounded by grey areas growing darker and darker and it is not always clear who can still be called a lexicographer and who not. And it does not help to look in a dictionary. Lexicographers need to pay more attention to the formulation of criteria that can help with a clear identification of lexicographers.

Will all real lexicographers please stand up?

\section{References}

Atkins, B.T.S. 2002. Then and Now: Competence and Performance in 35 Years of Lexicography. Braasch, A. and C. Povlsen (Eds.). 2002. Proceedings of the Tenth EURALEX International Congress, EURALEX 2002, Copenhagen, Denmark, August 13-17, 2002: 1-28. Copenhagen: Københavns Universitet, Center for Sprogteknologi. (18:2008)

Bergenholtz, H. and R.H. Gouws. 2012. Who is a Lexicographer? Lexicon 42: 68-78.

Gouws, R.H. 2006. Leerdergedrewe leksikografie. Tydskrif vir Taalonderrig 40(1): 72-84.

Gouws, R.H. 2011. Learning, Unlearning and Innovation in the Planning of Electronic Dictionaries. Fuertes-Olivera, Pedro A. and H. Bergenholtz (Eds.). e-Lexicography: The Internet, Digital Initiatives and Lexicography: 17-29. London/New York: Continuum.

Ilson, R. 1988. Introduction. International Journal of Lexicography 1(1): ii.

Johnson, Samuel. 1755. A Dictionary of the English Language. London: J. \& P. Knapton/T. \& T. Longman et al.

Lochner, J. de V. 2011. Woordeboek vir die Gesondheidswetenskappe/Dictionary for the Health Sciences. Cape Town: Pharos.

Wiegand, H.E. 1984. On the Structure and Contents of a General Theory of Lexicography. Hartmann, R.R.K. (Ed.). 1984. LEXeter '83 Proceedings. Papers from the International Conference on Lexicography at Exeter, 9-12 September 1983: 13-30. Lexicographica. Series Maior 1. Tübingen: Max Niemeyer Verlag.

Wiegand, H.E. 1998. Wörterbuchforschung. Berlin: Walter de Gruyter.

Wikipedia. The Free Encyclopedia. www.yourdictionaries.com.

Zgusta, L. 1971. Manual of Lexicography. The Hague: Mouton. 